\title{
Pro \\ Economic Analysis of Aldicarb on Citrus in the Indian River Area in Southeastern Florida
}

Production \& Marketing Reports

\author{
Lindsey Blakeley, ${ }^{1}$ \\ Richard Weldon, ${ }^{2}$ and \\ Gary Fairchild ${ }^{3}$
}

AdDITIONAL INDEX WORDS. mature citrus, resets, revenue-cost, net return, grapefruit

Summary. Aldicarb is a pesticide used on several crops to control citrus rust mite (Phyllocoptruta oleivors), citrus nematode (Tylenchulus semipenetrans) and other citrus pests. Analysis of previous research experiments indicates that this pesticide is beneficial to both orange (Citrus sinensis) and grapefruit (Citrus parasisi) production and that both cost savings and higher yields can be experienced in many types of groves. Actual grove data shows that net returns for mature grapefruit that receive aldicarb can be $\$ 500 /$ acre $(\$ 1235 / \mathrm{ha})$ greater than net returns for identical acreage that uses other pest control options. Also, based on

University of Florida, Department of Food and Resource Economics, P.O. Box 110240, Gainesville, FL 32611-0240.

This research was supported by the Florida Agricultural Experiment Station, and approved for publication as journal series R-09598.

${ }^{1}$ Graduate student.

${ }^{2}$ Associate professor; to whom reprint requests should be addressed; email weldon@fred.ifas.ufl.edu. ${ }^{3}$ Professor grove reset data, it is shown that with an application of aldicarb the resulting increased yields for 3-year-old trees more than cover the additional cost of applying the aldicarb.

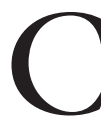

itrus grove managers face many key issues that influence their decisions over a growing cycle. Production, marketing and financial management are all vital to successful long-term management strategies. Pest control is a critical factor in the profitability of citrus production. In recent years, various chemical methods of controlling pests have come under scrutiny in terms of their influence on both profitability and the environment. Consequently managers desire pest control products that will satisfy production needs but that are also environmentally safe.

Temik (Aventis CropScience, Research Triangle Park, N.C.) is labeled for pesticide use on several citrus crops including oranges, grapefruit, and lemons (Citrus limon). Aldicarb, the active ingredient in Temik, has a very high efficacy on target insects, but it can also be extremely toxic to non-target organisms, including humans. Direct skin contact, dust inhalation, or consumption of contaminated drinking water are potential methods of aldicarb poisoning. Temik contains $15 \%$ active aldicarb ingredient by weight. The other $85 \%$ of Temik is inactive ingredients that carry the aldicarb to maintain the granular form and reduce dust during handling. The inactive ingredients also moderate the high water solubility of aldicarb to maximize root uptake and minimize leaching. Aldicarb is a restricted use pesticide in Florida and may be purchased only by persons with a pesticide license. Further regulations mandate that applicators of aldicarb be approved and registered.
Before 1984, the maximum allowable rate for applying Temik was 66 $\mathrm{lb} /$ acre $\left(74.0 \mathrm{~kg} \cdot \mathrm{ha}^{-1}\right)$. The high water solubility of aldicarb led to regulatory issues within the state of Florida. In 1983, Temik and other products with an aldicarb base were banned in Florida due to the discovery of traces of aldicarb in drinking wells around treated areas. Florida reinstated aldicarb in 1984 with significant modifications for use. Maximum application rate of Temik was reduced to $33 \mathrm{lb} /$ acre $\left(37.0 \mathrm{~kg} \cdot \mathrm{ha}^{-1}\right)$. A program was instituted to monitor the application sites throughout the state and ensure adherence to new regulations and management practices. Anew department was formed within the Florida Department of Agricultural and Consumer Services that would be strictly devoted to monitoring the application of aldicarb. Aldicarb application sites must be approved and water wells must have setbacks appropriate for the type of soil present. The application window was decreased from year-round to 1 Jan. through 30 Apr. of each year, the typical dry season in the state, to also decrease potential contamination.

Aldicarb controls citrus pests for citrus trees through uptake of the product to the leaves from the application site in the root zone of the tree. The root zone application provides a direct control for the nematodes.

Research indicates that proper aldicarb application and timing eliminates the need for a spring foliar pesticide application for both oranges and grapefruit. Citrus rust mites were virtually eliminated for up to $137 \mathrm{~d}$ post-treatment when applied at the 33-lb/acre rate while citrus nematode reduction has been shown to be very dependent upon rate usage (Childers et al., 1987). In 1992 and 1993, Stansly and Rouse (1994) tested pest response for various rates of Temik $[13,20$, and $33 \mathrm{lb} /$ acre $\left(14.6,22.4\right.$ and $\left.\left.37.0 \mathrm{~kg} \cdot \mathrm{ha}^{-1}\right)\right]$ on 14 year-old 'Hamlin' orange trees in Florida. The 13-lb rate provided control of the citrus rust mite for $110 \mathrm{~d}$ in 1993 and had exactly half the infestation present in the control group in 1992. The 20 and $33-\mathrm{lb} /$ acre rates provided significantly greater control well past $130 \mathrm{~d}$ post treatment in 1993 and an even greater reduction in infestation relative to the control in 1992.

Stansly and Rouse (1994) also tested yield response to various rates of aldicarb in the same study. Year One (1992) of the study showed no statisti- 
cal differences in yield of treated over untreated blocks, but yields in Year Two (1993) were significantly higher for the $13-\mathrm{lb} /$ acre application rate. It is theorized that this might be the result of aldicarb use during the first year or bloom stage of the second year's crop. Stansly and Rouse (1994) also reported that increases in fruit size were realized in both 1992 and1993.

Wheaton et al. (1985) also showed increases in yield per tree for aldicarbtreated blocks over untreated blocks in Year Two of their study of trees that were 15 to 22 years of age. Percentage yield increases were greatest in 'Valencia' variety. This supports the practice of using aldicarb in older and under-performing groves to increase production. Similar yield increases were found in a study (Bullock and Pelosi, 1995) of the influence of aldicarb application placement (bed tops or furrow) to grapefruit groves.

In another study (Bullock and Pelosi, 1992), aldicarb increased root growth in young trees, provided a shorterinterval to productivity and higher production at maturity when applied to young trees each year after being set. In this study, aldicarb was applied for 3 years (1988, 1989, and 1990) to 'Hamlin' orange groves that had been planted in 1987. All treatments increased growth and production of marketable fruit in the third year was significantly greater for the aldicarb-treated trees over the non-treated.

These experimental results provide strong evidence that aldicarb-treated citrus will experience both reduced pest populations and increased yields at the lower application rates associated with government regulations. However, it is not clear from these studies whether any additional monetary benefits from aldicarb use justify the additional costs associated with the application of aldicarb.

This study examines the productivity and profitability from aldicarb use under the conditions of lower application rates and reduced application in the Indian River area of Florida. The first study objective is to evaluate the economic return associated with using aldicarb to revitalize production in mature citrus. The second objective is to assess the cost effectiveness of using aldicarb to stimulate growth in new citrus. Actual production results from several groves in the Indian River County area are used to analyze the monetary benefits of in- corporating aldicarb in these distinctive production practices.

\section{Methodology}

The levels of revenue realized and expenses incurred by the grove determine the profitability of a citrus enterprise. For this study, revenue and expenses are calculated on a per-acre basis for each grove to allow comparisons for different size groves. Revenue is the average yield per acre times the price received per box for that grove and assumes that citrus-rust-mite-scarred culls have zero value. The expenses are the cash operating expenditures for grove care and cultural practices and include tree maintenance, weed control, fertilization, herbicides and pesticides. No management or ownership costs are included; therefore, the net returns per acre in this study represent the returns to land, trees, ownership and management.

The economic net return is for two different scenarios based on production data from four groves in the Indian River area. Table 1 shows the age, size, production levels and Temik application rates for these groves. All groves had been managed with standard citrus management practices for herbicides and fertilization, except as noted.

The first scenario reflects the impact of aldicarb on the profitability of revitalizing mature groves. Groves A and B are very mature (30+ years old) 'White' Grapefruit. These groves are under-producing by 280 to $32585-\mathrm{lb}(38.6-\mathrm{kg})$ boxes per acre $(26,676$ to 30,963 $\mathrm{kg} \cdot \mathrm{ha}^{-1}$ ) relative to standard production in the area. Both groves are located on extremely acidic soils in adjacent locations, managed by the same company using identical management schedules and are of old rootstock. Net returns to land, trees, ownership, and management were compared between the grove that used aldicarb and the grove that did not use aldicarb. The only management difference for these groves was that Grove A was not treated with aldicarb while Grove B had received a treatment of 24 $\mathrm{lb} / \operatorname{acre}\left(26.9 \mathrm{~kg} \cdot \mathrm{ha}^{-1}\right)$, thus allowing for the elimination of the spring pesticide spray that Grove A received.

The second scenario examined is the profitability of using aldicarb to stimulate growth in young citrus, in this case for the reset of citrus in established groves. For this scenario, two groves (C and D) of "colored" grapefruit are compared for net returns to land, trees, ownership, and management. These groves are two components of an original 38acre (15.4 ha) grapefruit grove. Grove $\mathrm{D}$ is actually a 15 -acre (6.1 ha) block of 2 -year-old tree resets while Grove $\mathrm{C}$ is the remaining 23 acres ( 9.3 ha) of the original grove. Consequently, identical management practices have been followed in the groves.

\section{Results and discussion}

Groves A AND B-MATURE CITRUS. Grove $B$, the treated grove, produced a yield of 288 boxes/acre (27442.0 $\mathrm{kg} \cdot \mathrm{ha}^{-1}$ ) while Grove A produced 241 boxes/acre $\left(22,960 \mathrm{~kg} \cdot \mathrm{ha}^{-1}\right)$, for a nominal difference of 47 boxes/acre $(4,478$ $\left.\mathrm{kg} \cdot \mathrm{ha}^{-1}\right)$. Grove B also produced fruit with a higherinternal quality that resulted in a higher price per box. Table 2 compares the cost structures, yield/acre, price received per box and resulting revenues and profits for the two groves.

The greater yield and quality of fruit in Grove B resulted in increased revenues of $\$ 350 /$ acre $(\$ 864.83 /$ ha) for the aldicarb-treated grove. This $30 \%$ greater revenue meant that the net return (above costs shown) of Grove B exceeded that of Grove A by $\$ 546 /$ acre (\$1,349.15/ha).

Groves C AND D-RESETS IN MATURE citrus Grove. Actual Year Three yields are not available for Groves C and D, however, the results from the Bullock and Pelosi (1995) study indicate that given a January aldicarb application, there should be a 4 -fold increase in yield for the reset trees in their third year. Results from Savage (1960) indicate that the expected yield for seedless grapefruit should average 0.5 box per tree, with a yield of one box per tree being expected under ideal growing conditions.

Table 3 shows the yield, revenues, expenses, and net return expected for Grove $C$ (the 23 acres of remaining $30+$ years-old grapefruit), which is expected to yield 494 boxes/acre $(47,064$ $\left.\mathrm{kg} \cdot \mathrm{ha}^{-1}\right)$, or this year's yield. Revenues would be $\$ 3,067 /$ acre $(\$ 7,578.45 /$ ha $)$ with cash operating costs of $\$ 724 /$ acre $(\$ 1,788.97 / \mathrm{ha})$ and results in a net return above costs shown of $\$ 2,344 /$ acre $(\$ 5,791.94 / \mathrm{ha})$.

The subsequent overall profit for the entire grove will be a function of how quickly the 15 acres of resets become productive. Without an aldicarb application and assuming (Muraro et al., 2000 ) a tree density of 91 trees / acre (or 224.9 trees/ha) and a third-year yield of 0.5 box $(19.3 \mathrm{~kg}$ ) per tree (the average yield from Savage, 1960), the expected 
Table 1. Tree age, grove size and production, and Temik (15\% aldicarb by weight) application rates for four grapefruit groves in the Indian River area of southeastern Florida, in 2000.

\begin{tabular}{|c|c|c|c|c|c|}
\hline Grove & $\begin{array}{l}\text { Age } \\
\text { Crop }^{z}\end{array}$ & $\begin{array}{c}\text { Grove size } \\
\text { (years) }\end{array}$ & $\begin{array}{l}\text { Yield in } 2000 \\
\quad(\text { acres })^{y}\end{array}$ & $\begin{array}{c}\text { Temik } \\
\text { (boxes/acre) }^{\mathrm{x}}\end{array}$ & $(\mathrm{lb} / \mathrm{acre})^{\mathrm{w}}$ \\
\hline A & White grapefruit & $30+$ & 38.5 & 241 & 0 \\
\hline $\mathrm{B}$ & White grapefruit & $30_{+}$ & 38.5 & 288 & 24 \\
\hline $\mathrm{C}$ & Colored grapefruit & 30 & 23 & 494 & 24 \\
\hline $\mathrm{D}$ & Colored grapefruit & 2 & 15 & 0 & 12 \\
\hline
\end{tabular}

${ }^{2}$ All grapefruit are seedless.

y. 1.0 acre $=0.405$ ha.

${ }^{x} 1$ box $/$ acre $=95.3 \mathrm{~kg} \cdot \mathrm{ha}^{-1}$

${ }^{w} 1 \mathrm{lb} /$ acre $=1.12 \mathrm{~kg} \cdot \mathrm{ha}^{-1}$.

Table 2. Net returns to land, trees, ownership, and management of white grapefruit grove A (Temik-treated) and B (no Temik) in the Indian River area of southeastern Florida, in 2000; Temik $=15 \%$ aldicarb by weight.

\begin{tabular}{|c|c|c|c|c|c|c|c|}
\hline Grove & $\begin{array}{c}\text { Temik } \\
(\text { lb/acre })^{y}\end{array}$ & $\begin{array}{c}\text { Yield } \\
{\text { (boxes/acre })^{\mathrm{x}}}^{\text {(boxes }}\end{array}$ & $\begin{array}{c}\text { Price } \\
(\$ / \text { acre })^{w}\end{array}$ & $\begin{array}{l}\text { Revenue } \\
\text { (\$/acre) }\end{array}$ & $\begin{array}{c}\text { Temik cost } \\
\text { (\$/acre) }\end{array}$ & $\begin{array}{c}\text { Total cost } \\
\text { (\$/acre })\end{array}$ & $\begin{array}{c}\text { Net return } \\
\text { (\$/acre) }\end{array}$ \\
\hline A & 0 & 241 & 4.81 & 1159 & 0.00 & 589 & 353 \\
\hline B & 24 & 288 & 5.24 & 1509 & 83.20 & 610 & 899 \\
\hline
\end{tabular}

${ }^{z}$ Includes the cost of Temik for Grove A.

1 $\mathrm{lb} /$ acre $=1.12 \mathrm{~kg} \cdot \mathrm{ha}^{-1}$.

${ }^{x} 1$ box $/$ acre $=95.3 \mathrm{~kg} \cdot \mathrm{ha}^{-1}$

w $\$ 1.00 /$ acre $=\$ 2.47 /$ ha.

Table 3. Estimated net returns to land, trees, ownership, and management from Temik (15\% aldicarb by weight) application to reset trees in colored grapefruit grove, in 2000 .

\begin{tabular}{|c|c|c|c|c|c|c|c|c|c|}
\hline Grove & $\begin{array}{c}\text { Area } \\
(\text { acres })^{z}\end{array}$ & $\begin{array}{c}\text { Temik } \\
(\text { lb/acre })^{y}\end{array}$ & $\begin{array}{c}\text { Yield } \\
{\text { (boxes/acre })^{\mathrm{x}}}^{\text {(boxes }}\end{array}$ & $\begin{array}{c}\text { Price } \\
(\$)\end{array}$ & $\begin{array}{l}\text { Revenue } \\
\left(_{(\$ / \text { acre })^{\mathrm{w}}}\right.\end{array}$ & $\begin{array}{c}\text { Temik } \\
\text { cost } \\
(\$ / \text { acre })\end{array}$ & $\begin{array}{c}\text { Total } \\
\text { cost } \\
(\$ / \text { acre })\end{array}$ & $\begin{array}{c}\text { Net return } \\
\text { (\$/acre) }\end{array}$ & $\begin{array}{c}\text { Net return } \\
\text { to C and D } \\
(\$)\end{array}$ \\
\hline $\mathrm{C}$ & 23 & 24 & 494 & 6.21 & 3068 & 83.20 & 724 & 2344 & \\
\hline $\mathrm{D}^{\mathrm{v}}$ & 15 & 0 & 45.5 & 6.21 & 283 & 0 & 640 & -358 & 48,538 \\
\hline $\mathrm{D}^{\mathrm{u}}$ & & 12 & 182 & 6.21 & 1130 & 48.56 & 689 & 441 & 60,524 \\
\hline $\mathrm{D}^{\mathrm{t}}$ & & 12 & 364 & 6.21 & 2260 & 48.56 & 689 & 1571 & 77,477 \\
\hline
\end{tabular}

${ }^{\mathrm{z}} 1$ acre $=0.4$ ha.

yl lb/acre $=1.12 \mathrm{~kg} \cdot \mathrm{ha}^{-1}$

${ }^{\mathrm{x}} \mathrm{l}$ box $/$ acre $=93.5 \mathrm{~kg} \cdot \mathrm{ha}^{-1}$

w $\$ 1.00 /$ acre $=\$ 2.47 /$ ha .

'If Temik has no effect on yield (assumes average yield of 0.5 box/tree)

"If Temik increase average yield by $4 \times$.

tIf a high yield ( 1 box/tree) and Temik has $4 \times$ effect on yield average.

yield would be 45.5 boxes / acre $(4,335$

$\left.\mathrm{kg} \cdot \mathrm{ha}^{-1}\right)$. With cash operating expenditures of $\$ 689 /$ acre $(1702.50 / \mathrm{ha})$, the reset acreage would have a net loss of \$-358/acre (\$-884.61/ha), situation $\mathrm{D}^{\mathrm{v}}$ in Table 3 . The net return to the total grove $\left(\mathrm{C}+\mathrm{D}^{\mathrm{v}}\right)$ with no aldicarb is estimated to be $\$ 48,538$.

The impact of aldicarb on grove returns is determined by the level of yields experienced above the 45.5 boxes/acre. If average grove conditions were experienced, then the work of Bullock and Pelosi (1995) would mean that the application of $12 \mathrm{lb} /$ acre $\left(13.4 \mathrm{~kg} \cdot \mathrm{ha}^{-1}\right)$ of Temik to the reset tree would improve the yield to 182 boxes/acre $(17,339$ $\left.\mathrm{kg} \cdot \mathrm{ha}^{-1}\right), \mathrm{D}^{\mathrm{u}}$ in Table 3 . The net return above operating costs would be $\$ 441$ / acre $(\$ 1,089.70 / \mathrm{ha})$ and the resulting profit earned by the entire grove would be $\$ 60,524$ or about $25 \%$ above that expected for the no-aldicarb situation. If the grove experiences ideal grow- ing conditions (Savage, 1960), it would be expected that yields in the reset acreage could be as much as 364 boxes/acre $\left(34,678 \mathrm{~kg} \cdot \mathrm{ha}^{-1}\right)$ with the application of aldicarb generating total grove returns of $\$ 77,478$. This analysis would indicate that the use of aldicarb on a 3-year-old tree would result in yield and profit levels similar to that of about a 5-year-old nonaldicarb-treated tree.

Aldicarb is a pesticide with efficacy on citrus rust mite, citrus nematode, and other pests. This control lasts beyond the traditional control times for normal spring foliar pest-control applications, and eliminates the need to use the spring foliar control in a management schedule. The evidence (from prior field studies, but not from this field study) indicates that the economic benefits come from not only these cost savings but also from increased revenues from higher yields, both in terms of boxes per tree and improved internal fruit quality. Field trials and the analysis of actual groves show that these benefits translate into higher returns for older, under-produc- ing groves, as well as improved returns for new/reset groves. Grove managers seeking tools to enhance profitability should examine aldicarb and determine if it fits their management schedule's needs.

\section{Literature cited}

Bullock, R.C. and R.R. Pelosi. 1992. Influence of Temik aldicarb soil treatments on growth of newly planted 'Hamlin' orange trees. Proc. Intl. Soc. Citriculture. 3:991-994

Bullock, R.C. and R.R. Pelosi. 1995. Influence of Temik aldicarb placement for production of 'Marsh' grapefruit in a bedded grove. Proc. Fla. State Hort. Soc. 108:122-125.

Childers, C.C., L.W. Duncan, T.A. Wheaton, and T. W. Timmer. 1987. Arthropod and nematode control with aldicarb on Florida citrus. J. Econ. Entomol. 80(5): 1064-1071.

Muraro, R.P., J.W. Hebb, and E.W. Stover. 2000. Budgeting costs and returns for Indian River citrus production, 1999-2000. Economic information report, Univ. of Fla. Gainesville, Dec. 2000.

Savage, Z. 1960. Citrus yields per tree by age. Fla. Agr. Ext. Serv. Econ. Ser. 60-8.

Stansly, P.A. and R.E. Rouse. 1994. Pest yield and response of citrus to aldicarb in a Flatwoods grove. Proc. Fla. State Hort. Soc. 107:69-72

Wheaton T.A., C.C. Childers, L.W. Timmer, L.W Duncan, and S. Nikdel. 1985. Effects of aldicarb on yield, fruit quality and tree conditions of Florida citrus. Proc. Fla. State Hort. Soc. 98:6-10. 